\title{
Intraoral Radiographic Processing Skills among Dentists in Saudi Arabia
}

\author{
Hisham Abbas ${ }^{1,2 \star}$, Abdullah Issam Arabi ${ }^{3}$, Badia Baroudi ${ }^{3}$, Shaima'a Makhdom ${ }^{3}$ (D), Mazen Ahmed Alwadani ${ }^{3}$, \\ Elaf Sami Al Akhdar ${ }^{3}$, Ahmad Majed Alshareef ${ }^{3}$ \\ ${ }^{1}$ Lecturer of Oral and Maxillofacial Radiology, Faculty of Dentistry, Cairo University, Giza, Egypt; ${ }^{2}$ Assistant Professor, Oral and \\ Maxillofacial Radiology, Vision Colleges for Education, Jeddah, Saudi Arabia; ${ }^{3}$ Intern, Vision College for Education, Jeddah, \\ Saudi Arabia
}



\section{Introduction}

Intraoral radiography is the most widely used imaging technique in dentistry, and since the debut of digital radiography in dentistry in the late 1980s [1], intraoral digital radiography has become more popular and has mostly supplanted analog film technology [2], [3], [4], [5], [6], [7], [8].

For intraoral digital radiography, there are two types of digital imaging technologies: The indirect technique, which uses a storage phosphor plate, and the direct technique, which uses a charged coupled device and complementary metal oxide semiconductor [2], [7].

According to the recent study, $45 \%$ of dentists who are using film-based systems were opposed to switching to a digital system. The major reasons were "expense" (67\%), "system complexity" (50\%), and "no benefit to change" (25\%) [7].

Other studies [4], [7], [8], [9] found that the utilization of intraoral digital techniques differed. A variety of benefits of digital intraoral radiography have been described, with the claim that switching from film to digital would result in significant improvements [10], [11]. Although some of the anticipated benefits do not appear to have realized, it is reasonable to conclude that time was saved, work was simplified, and communication was streamlined [12]. There are certain limitations, according to a couple of studies, because getting good X-ray images with a solid-state detector were more challenging than conventional film [10], [13]. When compared to working with film, more images were exposed and more retakes were necessary [14]. Retakes were more common with a solid-state detector than with film [15], contravening the as low as reasonably achievable principle [16], and solid-state users noted that detector alignment was challenging, resulting in more retakes [7].

Knowledge about the use of digital intraoral radiography among general dental practitioners (GDP) in Saudi Arabia is rare. The present study was designed to investigate the use of intraoral radiographic techniques (conventional and digital) among GDP in Saudi Arabia with a focus on its availability in workplace, ease of the technique, and recommended technique to be taught during undergraduate based on individual experience. 


\section{Methods}

The present study was performed from January 2021 to April 2021; ethical approval was obtained from institutional ethical committee and performed according to the principles described in the Declaration of Helsinki. All participants signed informed consent about the study at the beginning of the questioner.

The questionnaire was designed concerning demographic data, country, district, university, year of graduation, availability of radiographic technique available in workplace, which technique learned during undergraduate study, and which technique should teach during undergraduate study based on individual experience.

\section{Dentist selection}

GDP list was developed from different dental groups on social media. A questioner in the form of Google sheet was sent to that list and to improve the response rate, telephone calls were made in advance to all expected participants. In total, 750 questionnaires were sent out through different social media.

According to the graduation year, the participants were divided into recent (2017-2021), intermediate (2012-2016), old graduate (2000-2011), and elderly graduated (before 2000). According to the location, the participants divided into western, eastern, middle, and north areas.

Regarding the radiographic technique learned during the undergraduate study, the participants choose one of the following; digital (theory only), digital (theory and practical), conventional (theory and practical), digital (theory and practical) and conventional (theory and practical), conventional (theory only), and digital (theory only) and conventional (theory and practical).

Regarding advantages and disadvantages of radiographic technique, participants choose from associated list that includes (cost, complexity, technique difficulty, reduction of time between exposure and image display, image enhancement, and magnification and need of retake).

Finally, the participants were asked to recommend the radiographic technique that should taught during undergraduate study based on individual experience, availability of the technique, and technical problems associated with each one.

\section{Statistical analysis}

Statistical analysis was carried out using SPSS computer package (IBM SPSS Statistics for Windows, Version 25.0. Armonk, and NY: IBM Corp., USA). Regarding to descriptive statistics, frequency and percentage were used for qualitative variables.
Chi-square test was used to assess the differences in frequencies of qualitative variables. The statistical methods were verified, assuming a significant level of $p<0.05$ and a highly significant level of $p<0.001$.

\section{Results}

The study included 500 participants fulfilling the inclusion criteria with $386(77.2 \%)$ obtained their dental bachelor's degree from different governmental (n $=198)$ and private $(n=188)$ Universities/Colleges inside KSA. More than half of participants were graduated from Universities/Colleges in the Western Region while no participation received from the Eastern Region. About $62.2 \%$ were graduated within the past 5 years and in $47.6 \%$ digital and conventional (both theoretical and practical) dental X-ray processing was the technique learned in undergraduate training followed by the conventional (theoretical and practical) technique in 21\% (Table 1).

Table 1: General characteristics related to bachelor's degree of dental surgery

\begin{tabular}{|c|c|c|}
\hline Variables & $\begin{array}{l}\text { Frequency } \\
\mathrm{n}=500\end{array}$ & Percent \\
\hline \multicolumn{3}{|l|}{ The degree is obtained from } \\
\hline KSA & 386 & 77.2 \\
\hline Outside KSA & 114 & 22.8 \\
\hline \multicolumn{3}{|l|}{ Type of University/College inside KSA $(n=386)$} \\
\hline Governmental & 198 & 51.3 \\
\hline Private & 188 & 48.7 \\
\hline \multicolumn{3}{|l|}{ The University/College of graduation inside KSA ( $n=386$ ) } \\
\hline Al-Baha University & 16 & 4.15 \\
\hline Vision College (Jeddah) & 70 & 18.13 \\
\hline Vision College (Riyadh) & 47 & 12.18 \\
\hline Al-Jouf University & 15 & 3.89 \\
\hline Batterjee College & 22 & 5.7 \\
\hline Ibn Sina College & 33 & 8.55 \\
\hline Jazan University & 7 & 1.81 \\
\hline King Abdulaziz University & 33 & 8.55 \\
\hline King Khalid University & 8 & 2.07 \\
\hline King Saud Bin Abdulaziz University for Health Sciences & 4 & 1.04 \\
\hline King Saud University & 38 & 9.84 \\
\hline Najran University & 8 & 2.07 \\
\hline Prince Sattam Bin Abdulaziz University & 5 & 1.3 \\
\hline Princess Nourah Bint Abdulrahman University & 8 & 2.07 \\
\hline Qassim University & 9 & 2.33 \\
\hline Riyadh Elm University & 16 & 4.15 \\
\hline Taibah University & 12 & 3.11 \\
\hline Taif University & 5 & 1.3 \\
\hline Umm Al-Qura University & 30 & 7.77 \\
\hline \multicolumn{3}{|l|}{ University/College region inside KSA ( $n=386)$} \\
\hline Western region & 205 & 53.1 \\
\hline Northern region & 15 & 3.9 \\
\hline Middle region & 127 & 32.9 \\
\hline Southern region & 39 & 10.1 \\
\hline \multicolumn{3}{|l|}{ Graduation year } \\
\hline Within 5 years & 311 & 62.2 \\
\hline Within $6-10$ years & 56 & 11.2 \\
\hline Within $11-20$ years & 98 & 19.6 \\
\hline More than 20 years & 35 & 7.0 \\
\hline \multicolumn{3}{|c|}{ Dental X-ray processing technique learned in undergraduate training } \\
\hline Digital (T only) & 49 & 9.8 \\
\hline Digital ( $T$ and $P$ ) & 27 & 5.4 \\
\hline Conventional ( $\mathrm{T}$ and $\mathrm{P})$ & 105 & 21.0 \\
\hline Digital ( $\mathrm{T}$ and $\mathrm{P})$, Conventional ( $\mathrm{T}$ and $\mathrm{P}$ ) & 238 & 47.6 \\
\hline Digital ( $\mathrm{T}$ and $\mathrm{P}$ ), Conventional ( $\mathrm{T}$ only) & 10 & 2.0 \\
\hline $\begin{array}{l}\text { Digital ( } T \text { only), Digital ( } T \text { and } P) \text {, Conventional ( } T \text { only), } \\
\text { Conventional ( } T \text { and } P \text { ) }\end{array}$ & 37 & 7.4 \\
\hline Conventional (T only), Conventional ( $T$ \& P) & 18 & 3.6 \\
\hline Digital (T only), Conventional (T \& P) & 16 & 3.2 \\
\hline
\end{tabular}

Among participants, $58 \%$ were practicing dentistry in the Western Region while only $7 \%$ in the middle region with similar percent practicing for more 
than 20 years. About $65.4 \%$ were practicing in private facilities and in $40.2 \%$, the digital technique for dental $X$-ray processing was available while the conventional technique was available in $24.2 \%$ (Table 2).

Based on their work experience, when they asked about the processing method/s that should be taught in dental Saudi Universities/Colleges, the majority $(74.8 \%)$ preferred both digital and conventional techniques while the digital method only was preferred by $21 \%$.

The opinion of participants about the processing method/s that should be taught in dental Saudi Universities/Colleges was stratified according to different study variables (Table 3 ). In most variables, from $60.4 \%$ to $100 \%$ of participants preferred both processing methods.

This study demonstrated that advantages of digital technique included reduction of time between exposure and image display (81\%), image enhancement, and magnification (93.3\%), while disadvantages associated with the digital technique included technique difficulty $(74.8 \%)$ and need to retake $(64.6 \%)$. Regarding advantages of conventional technique included lower cost (60\%) and less complicated technique (30\%).

Table 2: General characteristics related to dentistry practice

\begin{tabular}{lll}
\hline Variables & $\begin{array}{l}\text { Frequency } \\
\mathrm{n}=500\end{array}$ & Percent \\
\hline $\begin{array}{ll}\text { Region of practicing } \\
\text { Western region }\end{array}$ & 290 & 58.0 \\
$\quad$ Northern region & 112 & 22.4 \\
$\quad$ Eastern region & 63 & 12.6 \\
$\quad$ Middle region & 35 & 7.0 \\
Duration of practicing & & \\
$\quad 5$ years or less & 311 & 62.2 \\
6-10 years & 56 & 11.2 \\
11-20 years & 98 & 19.6 \\
20 years or more & 35 & 7.0 \\
Place of practicing & & \\
$\quad$ Government & 120 & 24.0 \\
$\quad$ Private & 327 & 65.4 \\
$\quad$ Both & 53 & 10.6 \\
Type of dental X-ray processing available & & \\
$\quad$ Digital only & 201 & 40.2 \\
Conventional (developer and fixer) & 121 & 24.2 \\
Both & 178 & 35.6 \\
\hline
\end{tabular}

\section{Discussion}

Institutions play important role in modern society by giving knowledge to students and have become centers of revolution. Similarly, these institutions are responsible for developing highly competent, trained, and efficient students to meet society's needs. Any system that does not change according to technological environments will become fossilized. To avoid this, institutions must assess and modify their system's performance on a regular basis. Educational programs in dental institutions are responsible to provide dental students with knowledge and application skills [17].
Radiographs have become integral aspects of dentistry's diagnosis and therapy. Hence, GDP should know how to take and process radiographs [18], [19].

In this study, the response rate was $71.42 \%$ with most participants receiving a preparatory telephone call. The personal approach may have a positive effect on the response rate.

Digital and conventional radiological techniques (theoretical and practical) were taught to $47.2 \%$ of participants while, $21 \%$ of participants were taught conventional technique (theoretical and practical). Digital radiography techniques were available in $75.8 \%$ of workplaces in Saudi Arabia, while conventional radiographic technique was found in $59.8 \%$ in Saudi Arabia. Those findings explain comparable rates for using both radiological techniques in Saudi Arabia.

Advantages of digital technique include reduction of time between exposure and image display, image enhancement, and magnification which are in agreement with Berkhout et al. [10], and study of Parks and Williamson [11] while disadvantages associated with the digital technique include technique difficulty $(74.8 \%)$ and need to retake $(64.6 \%)$. This result is in accordance study of Bahrami et al. [13], and Berkhout et al. [10]. Regarding advantages of conventional technique included lower cost (60\%) and less complicated technique $(30 \%)$ which comparable to study of Anissi [7], Geibel [2].

In this study, $74.8 \%$ of participants recommended to learn both digital and conventional radiographic technique, while $21 \%$ of participants recommended to learn the conventional radiographic technique. The higher percent for recommendation to teach both techniques can be attributed to most participants had learned both techniques during their study and the availability of the digital technique in most workplaces. This was beside the advantages associated with digital radiographic technique. While, still percent of participants recommend to use the conventional radiographic technique due to lack of availability of digital radiograph in certain areas, presence of required skill for a practitioner in presence of any technical problem related to digital technique, beside the advantages of conventional radiographic technique.

\section{Conclusion}

However, intraoral digital radiographic technique is widely available in most regions in Saudi Arabia; it is recommended to teach both intraoral digital and conventional radiographic techniques during undergraduate study. 
Table 3: Relation between their opinion about the processing method/s that should be taught and different study variables

\begin{tabular}{|c|c|c|c|c|}
\hline \multirow[t]{2}{*}{ Variables } & \multicolumn{3}{|c|}{ Processing method that should be taught } & \multirow[t]{2}{*}{ p-value } \\
\hline & Digital $n=105(\%)$ & Conventional $\mathrm{n}=21(\%)$ & Both $\mathrm{n}=374(\%)$ & \\
\hline \multicolumn{4}{|l|}{ The degree is obtained from } & $0.001^{*}$ \\
\hline KSA & $93(24.1)$ & $19(4.9)$ & $274(71.0)$ & \\
\hline Outside KSA & $12(10.5)$ & $2(1.8)$ & $100(87.7)$ & \\
\hline \multicolumn{4}{|l|}{ Graduation year } & $<0.001^{*}$ \\
\hline Within 5 years & $77(24.8)$ & $7(2.3)$ & $227(73.0)$ & \\
\hline Within 6-10 years & $0(0.0)$ & $14(25.0)$ & $42(75.0)$ & \\
\hline Within $11-20$ years & $21(21.4)$ & $0(0.0)$ & 77 (78.6) & \\
\hline More than 20 years & $7(20.0)$ & $0(0.0)$ & $28(80.0)$ & \\
\hline \multicolumn{5}{|c|}{ Dental X-ray processing technique learned in undergraduate training } \\
\hline Digital (T only) & $14(28.6)$ & $0(0.0)$ & $35(71.4)$ & 0.146 \\
\hline Digital (T \& P) & $0(0.0)$ & $9(33.3)$ & $18(66.7)$ & $<0.001^{*}$ \\
\hline Conventional ( $\mathrm{T} \& \mathrm{P})$ & $26(24.8)$ & $12(11.4)$ & $67(63.8)$ & $<0.001^{*}$ \\
\hline Digital (T \& P), Conventional (T \& P) & $56(23.5)$ & $0(0.0)$ & $182(76.5)$ & $<0.001^{*}$ \\
\hline Digital (T \& P), Conventional (T only) & $3(30.0)$ & $0(0.0)$ & $7(70.0)$ & 0.653 \\
\hline Digital (T only), Digital (T \& P), & $0(0.0)$ & $0(0.0)$ & $37(100.0)$ & $0.001^{*}$ \\
\hline \multicolumn{5}{|l|}{ Conventional (T only), Conventional (T \& P) } \\
\hline Conventional ( $T$ only), Conventional ( $T$ \& P) & $4(22.2)$ & $0(0.0)$ & $14(77.8)$ & 0.664 \\
\hline Digital (T only), Conventional (T \& P) & $2(12.5)$ & $0(0.0)$ & $14(87.5)$ & 0.445 \\
\hline \multicolumn{4}{|l|}{ Region of practicing } & $<0.001^{*}$ \\
\hline West region & $70(24.1)$ & $7(2.4)$ & $213(73.4)$ & \\
\hline North region & $7(6.3)$ & $14(12.5)$ & $91(81.3)$ & \\
\hline East region & $21(33.3)$ & $0(0.0)$ & $42(66.7)$ & \\
\hline Middle region & $7(20.0)$ & $0(0.0)$ & $28(80.0)$ & \\
\hline \multicolumn{4}{|l|}{ Duration of practicing } & $<0.001^{*}$ \\
\hline 5 years or less & $77(24.8)$ & $7(2.3)$ & $227(73.0)$ & \\
\hline $6-10$ years & $0(0.0)$ & $14(25.0)$ & $42(75.0)$ & \\
\hline $11-20$ years & $21(21.4)$ & $0(0.0)$ & 77 (78.6) & \\
\hline 20 years or more & $7(20.0)$ & $0(0.0)$ & $28(80.0)$ & \\
\hline \multicolumn{4}{|l|}{ Place of practicing } & $<0.001^{*}$ \\
\hline Government & $30(25.0)$ & $0(0.0)$ & $90(75.0)$ & \\
\hline Private & $54(16.5)$ & $21(6.4)$ & $252(77.1)$ & \\
\hline Both & $21(39.6)$ & $0(0.0)$ & $32(60.4)$ & \\
\hline \multicolumn{4}{|l|}{ Type of dental X-ray processing available } & $<0.001^{*}$ \\
\hline Digital only & $44(21.9)$ & $0(0.0)$ & $157(78.1)$ & \\
\hline Conventional (developer and fixer) & $36(29.8)$ & $0(0.0)$ & $85(70.2)$ & \\
\hline Both & $25(14.0)$ & $21(11.8)$ & $132(74.2)$ & \\
\hline
\end{tabular}

\section{References}

1. Wenzel A. A review of dentists' use of digital radiography and caries diagnosis with digital systems. Dentomaxillofac Radiol. 2006;35(5):307-14. http://doi.org/10.1259/dmfr/64693712.

PMid: 16940477

2. Gijbels F, Debaveye D, Vanderstappen M, Jacobs R. Digital radiographic equipment in the Belgian dental office. Radiat Prot Dosimetry. 2005;117(1-3):309-12. http://doi.org/10.1093/rpd/ nci761

PMid:16461489

3. Jacobs R, Vanderstappen M, Bogaerts R, Gijbel F. Attitude of the Belgian dentist population toward radiation protection. Dentomaxillofac Radiol. 2004;33(5):334-9. http://doi. org/10.1259/dmfr/22185511

PMid:15585812

4. Shahab S, Kavosi A, Nazarinia H, Meharlizadeh S, Mohammadpour M, Emami M. Compliance of Iranian dentists with safety standards of oral radiology. Dentomaxillofac Radiol. 2012;41(2):159-64. http://doi.org/10.1259/dmfr/29207955 PMid:22301640

5. Aps JK. Flemish general dental practitioners' knowledge of dental radiology. Dentomaxillofac Radiol. 2010;39(2):113-8. http://doi.org/10.1259/dmfr/52763613

PMid:20100924

6. Alcaraz M, Velasco E, Martinez-Beneyto Y, Velasco F, Armero D, Parra Cantera M. The status of Spain's dental practice following the European Union directive concerning radiological installations: 11 years on (1996-2007). Dentomaxillofac Radiol. 2010;39(8):468-74. http://doi. org/10.1259/dmfr/20362385

PMid:21062940

7. Anissi HD, Geibel MA. Intraoral radiology in general dental practices-a comparison of digital and film-based X-ray systems with regard to radiation protection and dose reduction. Rofo. 2014;186(8):762-7. http://doi.org/10.1055/s-0034-1366256

PMid:24648236

8. Mauthe PW, Eaton KA. An investigation into dental digital radiography in dental practices in West Kent following the introduction of the 2006 NHS General Dental Services contract. Prim Dent Care. 2011;18(2):73-81. http://doi. org/10.1308/135576111795162893

PMid:21457627

9. Wenzel A, Moystad A. Experience of Norwegian general dental practitioners with solid state and storage phosphor detectors. Dentomaxillofac Radiol. 2001;30(4):203-8. http://doi. org/10.1038/sj.dmfr.4600613 PMid:11681481

10. Berkhout WE, Sanderink GC, Van der Stelt PF. A comparison of digital and film radiography in Dutch dental practices assessed by questionnaire. Dentomaxillofac Radiol. 2002;31(2):93-9. http://doi.org/10.1038/sj.dmfr.4600669 PMid:12076062

11. Parks ET, Williamson GF. Digital radiography: An overview. J Contemp Dent Pract. 2002;3(4):23-39. PMid: 12444400

12. Wenzel A, Moystad A. Work flow with digital intraoral radiography: A systematic review. Acta Odontol Scand. 2010;68(2):106-14. http://doi.org/10.3109/00016350903514426 PMid:20141365

13. Bahrami G, Hagstrom C, Wenzel A. Bitewing examination with four digital receptors. Dentomaxillofac Radiol. 2003;32:317-21. http://doi.org/10.1259/dmfr/14212871 PMid:14709607

14. Berkhout WE, Sanderink GC, Van der Stelt PF. Does digital radiography increase the number of intraoral radiographs? A questionnaire study of Dutch dental practices. Dentomaxillofac Radiol. 2003;32:124-7. http://doi.org/10.1259/dmfr/97410196 PMid: 12775667 
15. Sommers TM, Mauriello SM, Ludlow JB, Platin E, Tynddall DA. Pre-clinical performance comparing intraoral film and CCDbased systems. J Dent Hyg. 2002;76(1):26-33.

PMid:11935928

16. Nyathi T, Chirwa T, van der Merwe D. A survey of digital radiography practice in four South African teaching hospitals: An illuminative study. Biomed Imaging Interv J. 2010;6(1):5-11. PMid:21611065

17. Elangovan S, Mahabob MN, Jaishankar S, Kumar BS,
Rajendran D. Faulty radiographs: A cross-sectional analysis among dental college students in Namakkal District, Tamil Nadu, India. J Pharm Bioall Sci. 2016;8(1):116-8. http://doi. org/10.4103/0975-7406.191938.

PMid:27829760

18. White SC, Pharoah MJ. Oral Radiology Principles and Interpretation. $5^{\text {th }}$ ed. New Delhi: Elsevier Publications; 2004.

19. Karjodkar FR. Textbook of Dental and Maxillofacial Radiology. $2^{\text {nd }}$ ed. New Delhi: Jaypee Publications; 2009. 